知能と情報（日本知能情報ファジィ学会誌） Vol.30, No.1, p.51（2018）

\title{
用語解説
}

\section{複合現実感（Mixed Reality：MR）}

2015 年 1 月にマイクロソフト社が開発者向けに透過型のヘッドセット「HoloLens」を発表, 2016 年 3 月から米 国とカナダの開発者・法人向けに発売し，2016 年 12 月から日本国内で販売するようになった。2017 年には没入 型の「Windows Mixed Reality（MR)」対応のヘッドセットを発表した. マイクロソフトはこれら 2 つ異なる種類 のヘッドセットをMR という 1 つの用語にまとめ, MR が話題になっている.

この Mixed Reality（MR）という概念は，1994 年にP. Milgramによって提唱された。この概念では, 現実環境と バーチャル環境を連続した 1 次元で表現し，その間に現実環境をバーチャル環境の情報で拡張したものである AR (Augmented Reality) と,バーチャル環境を現実環境の情報で拡張したものである AV (Augmented Virtuality) を統 合・包含している，日本では 1997 年に当時の通商産業省の出資事業である「複合現実感システムに関する試験研 究」(通称，MR プロジェクト）でMR システム研究所が設立され，様々な先駆的な研究がされた。「複合現実感」 という用語は, この MR プロジェクトで使われたのが最初である.

HoloLens は, Kinect v2 と同様に ToF（Time of Flight）方式の梁度センサを使用しており, 現実の手によるジェ スチャー認識や操作ができ, SLAM（Simultaneous Localization and Mapping）により高速かつ高精度に空間マッピ ングもできる。 また，この空間マッピング機能により，複数人が HoloLens を着用し，同じ空間内で 3DCG な゙の バーチャル情報を共有することが可能になっている。これは MRに含まれる ARである.

一方, Windows MRヘッドセットは, VRヘッドセットである Oculus Rift や HTC-Vive, PlayStation VR のような 没入型であり，これは MR に含まれる AV であるといえる。 MRヘッドセットでは, 内部のカメラやセンサからの 情報で位置を把握する方式を採用しているため，外部にカメラやセンサを設置する必要がない，それにもかかわ らず，他のVRヘッドセットと比べて，わずかに遅延を感じる程度である．様々なメーカーから Windows MR ッドセットが発表され，MRの普及に進もうとしている。

（石川工業高等専門学校 電子情報工学科 越野 亮）

\section{日本語プログラミング言語なでしこ}

なでしこはIPA（情報処理推進機構）の 2004 年度未踏ユースプロジェクトに採択された Windows 上で動作す るフリーのプログラミング言語である。しかし Windows エミュレーター的存在の WINEをインストールすること により作成されたアプリケーションのほとんどがLinux, macOS 上でも動作する.

なでしこの最も大きな特徵は日本語を用いてプログラムを記述することである，これによりソースコード自体 がアルゴリズムを日本語で表記したもののようになり，知識がない者からのプログラム可読性を高めている，他 の長所としてファイル処理や文字列処理, 画像処理, ネットワークなど多くの機能が用意されている点があげら れ，なでしこだけでプログラミングに求められる一通りの作業ができる. Word Pxcel, PowerPoint, Access な ど Windows 上で動く主なアプリケーションとの連携も強く意識されている. 次のソースコードは本学会 HP の イベント情報をWord から印刷する。『「http://www.j-soft.org/」から HTTP データ取得。それを SJIS 変換。それか ら「 div/table/tbody/tr/td/p/p/a」の階層夕グ切り出し。それから夕グ削除。それの「\&quot;」を「”」に置換。それの $\lceil$ \&amp;」を「\&」に置換。それの「\&1t;」を「<」に置換。それの「\&gt;」を「>」に置換。それの「\&nbsp;」を $「 」 に$ 置換。それの「\&copy;」を「?」に置換。ワード起動。ワード新規文書。(「イベント情報」\&改行＆改行 \&それ）をワード文章追加。ワード印刷。9 秒待つ。おわり。』 動作確認 2017 年 12 月 25 日

プログラミング言語の学習初期ではコマンドラインシェル上で動作するアプリケーションを作成させられるこ とが多い，その場合シェルの知識も必要になるが，なでしこは簡単なプログラムでも独自のウィンドウで動作す るのでその必要が無い，専用のなでしこエディタは,ソースコードをインタプリ夕言語方式でそのまま実行する. しかしソースコードを実行形式 (.exe) ファイルに変換することも可能であり,その場合実行する側のPCへのな でしこのインストールは必要無い. 